\title{
PALAEONTOLOGY
}

\section{Plankton in a greenhouse world}

The Palaeocene-Eocene Thermal Maximum was marked by global warming and ocean acidification. Fossil and experimental analyses show that different species of marine calcifying algae responded very differently to the environmental upheavals.

\section{Gerald Langer}

espite their tiny size, coccolithophores - single-celled phytoplankton that range from 5 to 25 micrometres in diameter - play a key role in marine food webs and the global carbon cycle. They also secrete a calcium carbonate shell, making them substantial contributors to marine carbonate cycling. Laboratory experiments suggest that coccolithophores may be vulnerable to ocean acidification caused by anthropogenic carbon dioxide emissions ${ }^{1,2}$. Some species, however, may have the ability to adapt to higher concentrations of dissolved $\mathrm{CO}_{2}$ (refs 1,2 ), but not necessarily at the current rate of acidification ${ }^{3}$. The fossil record of coccolithophores extends for tens of millions of years, and can provide insight into ecosystem responses to environmental change. One particular area of focus has been the Palaeocene-Eocene Thermal Maximum (PETM), a period of abrupt warming and ocean acidification about 56 million years ago. Writing in Nature Geoscience, Gibbs and colleagues ${ }^{4}$ show that changes in coccolithophore growth rate during the peak of the thermal maximum were species-specific.

Each coccolithophore cell is surrounded by a shell, termed coccosphere, that is comprised of intricately shaped individual calcite platelets known as coccoliths (Fig. 1). However, the calcite is only stable in waters that are saturated with respect to calcite, and rising amounts of dissolved $\mathrm{CO}_{2}$ in the oceans cause the saturation state of calcite to decline. Predicting the coccolithophore response to current ocean acidification has therefore become a key challenge for marine biologists. Laboratory experiments have shown that coccolithophores are indeed sensitive to seawater $\mathrm{pH}$ and dissolved $\mathrm{CO}_{2}$, temperature and nutrient concentration, all of which are impacted by anthropogenic $\mathrm{CO}_{2}$ emissions.

However, coccolithophore responses to environmental disturbances in culture are by no means uniform. Instead, they differ between species and even between different clones within a species ${ }^{1}$. In fact, Emiliania huxleyi, the most abundant extant coccolithophore, is capable of adapting to rising $\mathrm{CO}_{2}$ and decreasing

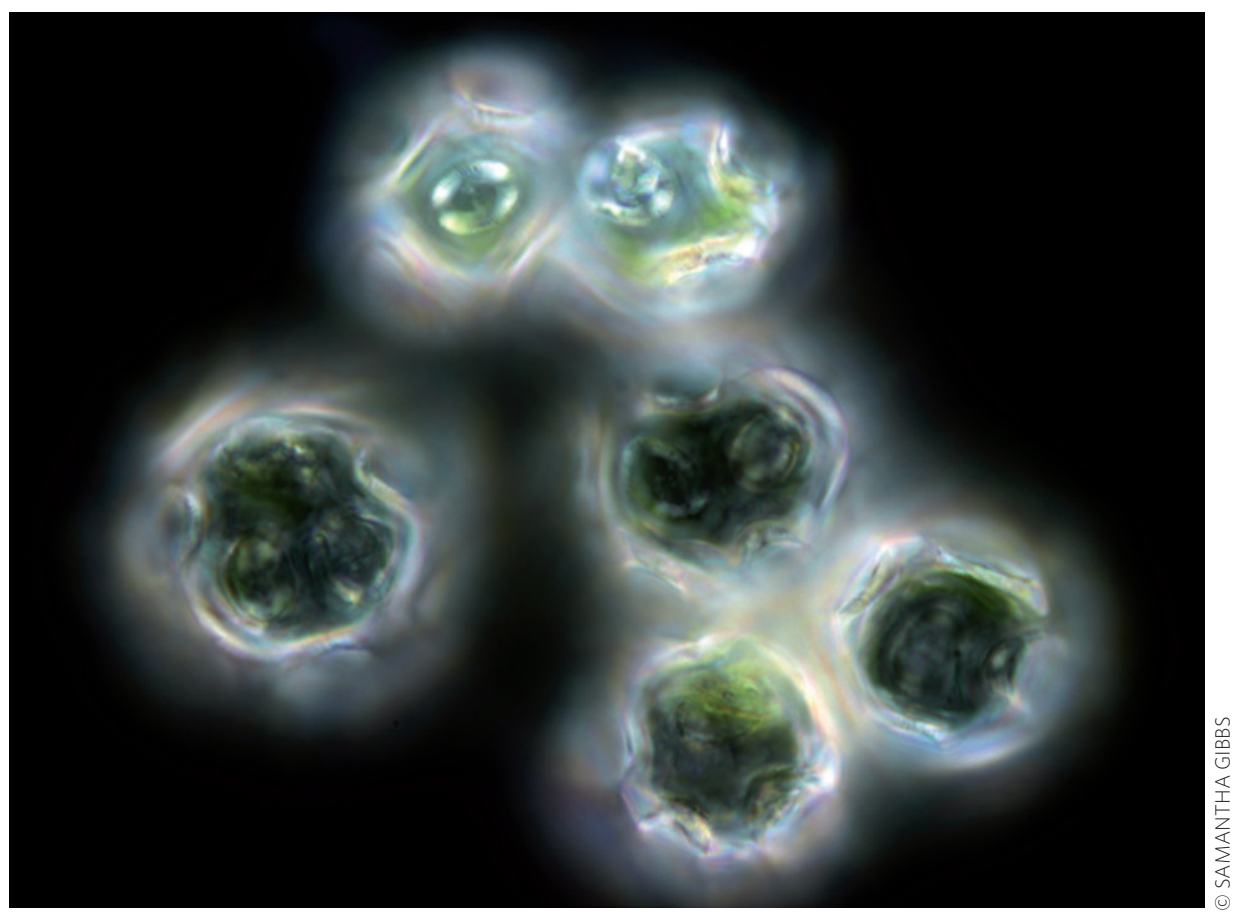

Figure 1 | Coccolithophores in culture. The response of coccolithophores, a key part of the marine food web, to future climate change and ocean acidification is uncertain. Looking at a period of global warming and ocean acidification 56 million years ago, Gibbs and colleagues ${ }^{4}$ reveal that the cell geometry of two species of coccolithophores showed different responses to the environmental stress. Using culture experiments, they showed that the different cell geometries reflect changes in growth rate during the Palaeocene-Eocene Thermal Maximum, with Toweius pertusus dividing rapidly throughout the event and Coccolithus pelagicus dividing slowly.

$\mathrm{pH}$ in experiments with relatively short time-frames ${ }^{2}$. This diversity in responses highlights the importance of complementary studies. The PETM is generally considered to be the closest geological approximation to the current situation, because it features a rapid rise in atmospheric $\mathrm{CO}_{2}$ levels and temperature ${ }^{5,6}$. Analyses of the PETM fossil record of coccolithophores have primarily centred on questions related to biogeography and evolutionary turnover ${ }^{7,8}$.

Gibbs and colleagues ${ }^{4}$ have developed a tool to assess the response of the coccolithophore growth rate at a cellular level. They present biometric data of complete fossil coccospheres of two dominant Paleocene-Eocene taxa, Coccolithus pelagicus and Toweius pertusus. They examine whether coccosphere geometry - coccosphere diameter, number of coccoliths per coccosphere, and coccolith size - changed across the PETM. Their most striking finding is a small range of cell geometries among the Toweius fossils, in contrast to a relatively large range in the Coccolithus. Specifically, the coccosphere diameter and number of coccoliths per cell of Coccolithus are higher at the peak of the PETM than in pre- and post-PETM samples. However, the reason for this disparate response was not immediately clear from the fossil record alone. 
To interpret their PETM data, Gibbs and colleagues $^{4}$ used a novel approach to identify the crucial relationship between the cell geometry they observe and the growth phase represented by that geometry. They placed a descendant of Toweius, namely Emiliania huxleyi, and Coccolithus pelagicus in culture experiments run with phosphorus limitation. In this type of experiment, the cells initially displayed normal, exponential growth but, as a consequence of phosphorus shortage, they then stopped dividing and entered a stationary phase. The exponentially growing cells of both species were characterized by smaller coccospheres and less coccoliths per coccosphere than cells in the early stationary phase of growth. Applying this relationship to the PETM data, Gibbs and colleagues concluded that the cell geometry of fossil Toweius is indicative of exponential growth throughout the PETM, whereas the cell geometry of fossil Coccolithus suggests that the cells at the peak of the PETM were dividing very slowly. This conclusion is reasonable, not least because it is backed up by field samples from the North

Atlantic Ocean.
This method establishes a new way to discern differences in growth phase and rate from the coccolithophore sedimentary archive. The only other tool available to reconstruct growth and calcification rates is the Sr/Ca ratio of coccoliths. Interestingly, neither Toweius nor Coccolithus display a change in coccolith $\mathrm{Sr} / \mathrm{Ca}$ ratio across the PETM $^{9}$. Although by no means necessarily a discrepancy, this fact seems to be puzzling. Only a combination of experiment-, fieldand sediment-based research can finally resolve this issue.

The species-specific response identified also raises interesting evolutionary questions. Coccolithus seems to have suffered during the environmental changes of the PETM, whereas Toweius did not, at least in terms of growth rate. Gibbs and colleagues therefore infer that Toweius and its evolutionary lineage (represented today by the cosmopolitan Emiliania huxleyi and Gephyrocapsa) are more adaptable - and hence more successful in the long term - than Coccolithus, which is limited in range and abundance in the modern oceans. It remains an open question whether Emiliania and Gephyrocapsa will do better than Coccolithus in the modern, warming and acidifying ocean.

Gibbs and colleagues ${ }^{4}$ have shown that the coccolithophore response to warming and acidification during the PETM was speciesspecific, suggesting that whatever their response to future anthropogenic changes, it might not be uniform across the taxa.

Gerald Langer is in the Department of Earth Sciences, University of Cambridge, Downing Street, Cambridge, CB2 3EQ, UK.

e-mail: gl345@cam.ac.uk

References

1. Langer, G., Nehrke, G., Probert, I., Ly, J. \& Ziveri, P. Biogeosciences 6, 2637-2646 (2009).

2. Lohbeck, K. T., Riebesell, U. \& Reusch, T. B. H. Nature Geosci. 5, 346-351 (2012)

3. Caldeira, K. \& Wickett, M. E. Nature 425, 365 (2003).

4. Gibbs, S. J. et al. Nature Geosci. 6, 218-222 (2013).

5. Zachos, J. C. et al. Science 302, 1551-1554 (2003).

6. Zachos, J. C. et al. Science 308, 1611-1615 (2005).

7. Gibbs, S. J., Bralower, T. J., Bown, P. R., Zachos, J. C. \& Bybell L. Geology 34, 233-236 (2006).

8. Gibbs, S. J., Bown, P. R., Sessa, J., Bralower, T. J. \& Wilson, P. A Science 314, 1770-1773 (2006).

9. Stoll, H. M., Shimizu, N., Archer, D. \& Ziveri, P. Earth Planet. Sci. Lett. 258, 192-206 (2007)

\section{PLATE TECTONICS}

\section{Calling card of a ghost continent}

Where continents break apart, new ocean basins are formed. The discovery of ancient continental minerals on a young, volcanic island suggests that parts of the Indian Ocean floor may be underlain by fragments of a long-lost continent.

\section{Conall Mac Niocaill}

O ceanic crust is created at midocean ridges where tectonic plates separate, and recycled back into the Earth's interior at subduction zones where tectonic plates converge. The cycle of production and destruction of oceanic crust means that the age of the oldest ocean floor is less than 200 million years old $^{1}$. Writing in Nature Geoscience, Torsvik et al. ${ }^{2}$ identify zircon minerals on the ocean island of Mauritius, western Indian Ocean, that are between 1,970 and 660 million years old, implying that slivers of ancient continental rocks may be preserved beneath the sea floor.

During continental breakup, the continental crust is stretched and thinned. Decompression melting in the underlying mantle creates magma that rises upwards to form new oceanic crust ${ }^{3}$ and a mid-ocean ridge spreading centre is initiated. As the ocean basin gradually grows in size, the broken continental parts are forced away from each other.
The Indian Ocean formed in this way about 85 million years ago, when the Indian sub-continent broke away from Madagascar on its northward path towards Asia. The Seychelles, too, were probably once joined to the Indian sub-continent north of Madagascar: this archipelago of islands is partly composed of continental crust and is now stranded in the western Indian Ocean ${ }^{1,4}$. Madagascar and the Seychelles are now situated thousands of kilometres away from the Indian continent to which they were once joined. The intervening oceanic crust is stippled with numerous high ridges and plateaux. Some of these rises form islands, such as the island of Mauritius in the western Indian Ocean (Fig. 1). The ridges, plateaux and islands were thought to be relatively young, formed of basaltic lavas that erupted from volcanoes above the Réunion mantle plume over the past 65.5 million years ${ }^{5,6}$.

Torsvik et al. ${ }^{2}$ analyse beach sands from the island of Mauritius. The sands are derived from very young basaltic lavas that are less than 9 million years old, yet they were found to contain zircon minerals that are much older than any oceanic crust on Earth, with Proterozoic ages of 1,970-660 million years. Zircons are common in continental crust, but they are not stable in basaltic melts. The question now arises of how the minerals got to these basaltic sands, given that Mauritius lies some $900 \mathrm{~km}$ away from the nearest known source of continental material. Torsvik and colleagues suggest that the source of the zircons must lie beneath Mauritius in the form of fragments of old continental crust. They suggest that the older material was melted and incorporated into the young basaltic lavas before they erupted as the oceanic crust passed over the Réunion mantle plume.

Continental fragments cannot be inferred from old zircons alone, however, so it is important to ascertain whether there are other lines of evidence for continental crust beneath Mauritius. Using measurements 